AWEJ for Translation \& Literary Studies, Volume 4, Number4. October 2020

DOI: http://dx.doi.org/10.24093/awejtls/vol4no4.4

Pp.43-57

\title{
A Critical Controversy: Reader-Response Theoreticians Opposing New Critics
}

\author{
Alanoud Abdulaziz Alghanem \\ Department of English Literature, Faculty of Languages \\ Princess Nourah bint Abdulrahman University \\ Riyadh, Saudi Arabia
}

\begin{abstract}
The present study is theoretically oriented proposing to re-read some major tenets of the New Critics and the reader-response critics in an attempt to reconsider the objective theory of the New Critics to test whether it is sufficient in catering for all aspects of a text. It works via the exploration of both protocols set by a number of the major founders of both theories aiming to reveal the oppositions, commonalities as well as undeclared similarities. The critical controversy will thus be brought to light, in a bid to point out the shortcomings of each approach. Throughout this exploration, the study demonstrates that the ontological approach of the New Critics becomes incomplete and doubtful. It proves that the New Critics' 'affective fallacy' has sprouted the postmodern theory of the reader-response criticism where the reader is no longer a passive recipient, but an active agent who fills in the blanks and formulates meanings. Thus, the study concludes by proving that there are some commonalities between the New Critics and the Readerresponse adherents highlighting the triumph of the latter in undermining the New Critics' objectivity. The significance of the study lies in adopting the reader-response approach per se in the re-reading of the New Critics' doctrines where the researcher comes up with new findings that testifies the crucial role of the reader/researcher in the production of new interpretations. The study concludes with some recommendations for further use.

Keywords: Literary criticism, new criticism, objective theory, reader response theory

Cite as: Alghanem, A.A. (2020). A Critical Controversy: Reader-Response Theoreticians Opposing New Critics. Arab World English Journal for Translation \& Literary Studies 4 (4) 4357. DOI: DOI: http://dx.doi.org/10.24093/awejtls/vol4no4.4
\end{abstract}




\section{Introduction}

The American New Critics emerging in the 1920s established a new professional criticism in British higher education. This Anglo-American movement, with its neutral nature and refusal to concern itself with context, shifted all its foundations in how the text speaks its own meaning, emphasising objective criticism and focusing on the study of words on the page and digging out the interrelation between selected devices within the text. This school of criticism that dominated the literary scene during the first part of the twentieth century received hostile criticism later on for the objectivity it forces on a text and demolishing the role of the reader in the process of interpretation. During the 1950s and early 1960s, studies concentrated on the reception of texts and the response of readers, thus opening the door to a new critical trend: the reader-response theory. These latter critics undermined the approach of the New Critics by dealing with the text as a function of its reader or collective readers. Yet it should be noted that:

Reader-response critics define their work as a radical departure from New Critical principles, but . . . closer look at the theory and practice of these critics will show that they have not revolutionized literary theory but merely transposed formalist principles into a new key. (Tompkins, 1980, p. 201)

This recent criticism shifts the focus from the interpretation of meaning embedded in a text to the process of reading. The new definitions suggested by these critics were quite shocking to those formalists who were seeking to emphasise the objectivity of interpretations.

This dichotomy between two views is yet to be understood in its entirety. Therefore, the work presented in this paper explores the objective theory of the New Critics to ascertain its capability to cater for all aspects of a text and to explore whether by isolating the text from the circumstances of its time, it adversely affects the inherent effectiveness of the text involved. The opposition calls to investigate the reader-response theory that abandons the objective critical attitude. In an attempt to pinpoint the major qualities that characterise each of the two theories, the present paper explores both protocols set by key founders of both theories. This investigation will work on multiple levels to reveal the oppositions, overlaps as well as undeclared similarities.

The study can be broadly divided into two domains. The first part presents a re-reading of some essays by Eliot as well as by Richards and Brooks to show the adequacy or inadequacy of their protocols in illuminating all aspects of a literary text. This re-reading shows why recent critics severely disapproved and some repudiated their methods and at the same time highlighting the misconceptions of their protocols. The second focus will give an overview of the reader-response theory and its theoreticians and doctrines, which reject the New Critics principle of the affective fallacy by considering the reader as the controlling force and the shaper of meaning. The study will conclude by proving points of commonalties and differences between the two approaches, and that the New Critics have paved the way for the rise of the reader-response theorists. 
AWEJ for Translation \& Literary Studies Volume, 4 Number 4 October 2020

A Critical Controversy: Reader-Response Theoreticians

Alghanem

Literature Review

Eliot and the New Critics

Following Mathew Arnold's (1970) wake, Eliot focuses on text with the assumption that earlier critics focused on the poet not the poem. However, this argument is controversial for the title of Eliot's famous essay "Tradition and the Individual Talent" places his argument within the frame of the poet's "individual talent" and its handling of tradition. Thus, the producer of the text cannot be marginalised. Eliot (1972b) admits that the individual talent works within tradition that cannot be inherited but rather needs a "great labour", and it also needs a "historical sense" (p.71). The comments made are addressed to both poets and critics. Past and present inform one another and they co-exist with each other. No poet exists alone and therefore he cannot have "his complete meaning alone" (Eliot, 1972b, p. 72). There is always a relation with the others where "the poet must be very conscious of the main current" and must be aware of "the mind of his own country" (Eliot, 1972b, pp. 72-73). This proves that the extra-textual influences cannot be ignored. This consequently deviates from the objectivity of the poet's theory.

Eliot raises an important issue about literary tradition by showing how it is governed by external experiences. Learning about the past requires a "surrender of the self" (1972b, p. 73). Both poets and critics must focus on the composition, the form of "a new compound" ( $p$. 74). The poet's mind is the catalyst that transmutes the mixture into a new form. Here the author meets with Brooks who confirms that ideas are interrelated and fused in a complex indirect manner. What gives power to the text is its technique and language. Brooks (1972) confirms that the poem gets its power from the "paradoxical situation" (p. 294). The method "is always indirect", yet compressed and precise (Brooks, 1972, p. 296). Brooks (1972) agrees with Eliot that literary language is slightly altered in which words are "juxtaposed in new and sudden combinations" (p. 259). These discussions end with a production of "a meaning" explored via the critic's securitisation of the terms that are "continually modifying each other" (pp. 295-296). Thus, Brooks' statement bears within its structure its own contradiction, for the phrases "connotations" (p. 295) and the "implications" (p. 297) suggest that the text offers meaning(s), not a single meaning, which are explored by the critic/reader. Richards (1972a) showed how emotive language can be when compared with referential language. Emotive language is used "for the sake of the effects in emotion and attitude produced by the reference it occasions" (p. 112). Richards (1972a) thus attacked the notions that every word has a correct/proper meaning of its own. Contexts are ever changing and they always determine and shape word meaning.

This re-reading of Eliot's essays and of other New Critics reveals several observations that were misread by earlier critics. Eliot argues that the function of the poet is not to find new emotions, but to use existing ones in a different manner. These two latter observations link directly with the reader-response theorists who highlight the active role of the critic/reader, which in turn links the New Critic/reader's scrutiny and the meaning(s) they structure. The second observation is that of the usage of common themes, feelings and "not to find new emotions" (Eliot, 1972b, p. 76). This links with the reader-response theorist Barthes (2001) who claimed that "a text is not a line of words releasing a single theological meaning ... but a multi-dimensional space in which a variety of writings, none of them original, blend and clash" (p. 188). The author to Barthes mixes writings and bears a "dictionary" (p. 128) from which writing is created. Richards (1972b, pp. 110-111) 
concluded by saying that poetry performs a therapeutic function by coordinating a variety of human impulses into an aesthetic whole, hoping both the writer and reader maintain their psychological well-being. This claim allows later theoreticians to stretch the umbrella to psychoanalytic studies of author or reader.

Brooks (1972) deals with the literary text as a self-sufficient verbal artefact: "The poet, within limits, has to make up his language as he goes" (p. 295). This is made clear at this point through a focus on the preface of Brooks (1947) which together with Brooks and Warren (1976) present exemplary instances of new critical doctrines. Yet, Brooks (1947), states that "the temper of our times is strongly relativistic" and affirms a necessity of seeing "what residuum, if any, is left after we have referred the poem to its cultural matrix" (p. vi). Such statements affirm the importance of literary history and when we probe into his analysis of William Wordsworth's sonnets or Alexander Pope's writing as well as John Donne's "Canonization", we realise that Brooks was deeply involved and knowledgeable of their historical background. However, Brooks (1947) goes on to state that poetry should exist "as poetry" and therefore the attempt must be made "to view it sub specie aeternitatis". Otherwise, "the poetry of the past becomes significant merely" as "a political, or religious, or moral instrument" (pp. vi-vii). Curiously enough, this caution echoes a present one asserted by the New Historicism.

Eliot (1972a) discusses the function of the critic, declaring that a large part of critical writing is "really creative" (p.82). The work of art, the author insists, is "autotelic; and that criticism, by definition, is about something other than itself . . . The critical activity finds its highest, its true fulfilment in a kind of union with creation in the labour of the artist" (p.82). Eliot (1972a) concluded that a critic , "must have a very highly developed sense of fact", which, as the author continues to say, "is something very slow to develop, and its complete development means perhaps the very pinnacle of civilization" (p. 82). The value of the practitioner's criticism is to help readers deal with the knowledge the critic transfers in the similar way the critic did. "Comparison and analysis" are the critic's major tools (p. 83). These chief tools should be handled with care for the worry is that critical theories/readings may end up supplying opinion instead of "educating taste" (p. 83). Eliot insists on choices made by the "reader/critic" or the receiver of that criticism. These late observations ironically link Eliot with the reader-response critics who place close attention to the language and the reader's freedom to create their specific interpretation of that structure. Rosenblatt (1978) observes that Eliot's key term "objective correlative... does imply the presence of a reader, since the adequacy of the objective correlative depends on what it can evoke". The emotions evoked, she states, "requires the reader's active contribution" (pp. 102-103).

The earlier discussions clearly illustrate that the language of the text is the major concern of the New Critics. Accordingly, the present discussion flows into the modern and postmodern current of discourse analysis. Abrams (1993) stated that discourse analysis "concerns itself with the use of language in a running discourse, continued over a sequence of sentences and involving the interaction of speaker (or writer) and auditor (or reader) in a specific situational context" (pp. 232233). Benveniste (1971) contrasted discourse with the language system and stated that:

Arab World English Journal for Translation \& Literary Studies 
Discourse must be understood in its widest sense: every utterance assuming a speaker and a hearer, and in the speaker, the intention of influencing the other in some way . . . it is also a mass of writing that reproduces oral discourse or that borrows its manner of expression and its purpose: correspondence, memoirs, plays, didactic works, in short, all genres in which someone addresses himself [sic] as the speaker, and organizes what he says in the category of person. (pp. 208-209)

Mills (1997) observes that discourses "do not exist in a vacuum but are in constant conflict with other discourses and other social practices" (p. 19). This agrees with the argument of Eliot (1972b) who observed that a text is produced through the writer's historical sense and awareness of the present, and that nothing is new as a thought but what makes it sound new and different is the unique structure and power of expression: its purposiveness. Such definitions should be re-read via the New Criticism to reveal meeting or departing points. First, the New Critics saw language as a sequence of structure reproduced through contact with earlier readings. The power of the text arises from its complex, uncommon language that finally causes an effect. Second, the text structure creates communication between artist and reader, as Eliot (1972a), Richards (1972b) and Brooks (1947) claimed. Thus, the postmodern definitions of discourse are built on the old new critical theory.

In short, though it dominated literary criticism for half a century and gained wide popularity in universities and publications, the New Criticism's approach is rejected by many critics for having shortcomings. The limitations of New Criticism approach are in fact well presented by the critical comments of Said (1983):

Textuality ... as it is practiced in the American academy today, literary theory has for the most part isolated textuality from the circumstances, the events, the physical senses that made it possible and render it intelligible as the result of human work. (p. 4)

His accusation charges the theory of impoverishing textuality. He actually finds that critics ultimately take a "passive" and "sterile view" (p. 221) of the pragmatics of textual power.

Being too preoccupied with textual study, the New Critics made of the reader a passive recipient while the reader-response approach sought to explore the diversity of readers' responses to literary works. Besides, by marginalising or ignoring of the intentions of the author, the New Critics demolish the psychological aspect and forget that the work is a reflection of the self or an expression of emotion. All extra-textual material that the New Critics ignored were redefined, erasing the line dividing historical and literary material. However, though Eliot, in a later phase of writing, as well as other New Critics maintained their formalistic thoughts, they developed their critical views to include historical, sociological and ethical matters. Towards the thirties and forties, Eliot, for instance, wrote much social criticism. Canary (1982) devoted a whole chapter on critics who addressed with Eliot's social and cultural views, elaborating that Eliot's (1928) "growing interest in political issues was mirrored in the articles he chose to print in the Criterion (1922-39), and his own editorial comments, as the conflict between fascism and communism

Arab World English Journal for Translation \& Literary Studies 
replaced the conflict between Classicism and Romanticism" (p. 116). Canary (1982) also notes that many of Eliot's post-war essays touched on social issues.

More importantly, Burke (1967) the pioneer of pluralistic approaches, though referred to as a New Critic, oriented from the New Critics' protocols during its peak and hence reflected some of their limitations. The author explored biography, politics, psychology, sociology and anthropology, ethics and religion, which all affected other critics later on. The main focus of critical analysis according to Burke (1967) should be in the structure of the work, which has some aims behind it. One of these aims is the sociological function. In sum, the hegemony of New Criticism started to deteriorate in the 1960s with the increased interest in extrinsic factors by the reader-response critics. This shift in literary criticism intersects with the attitude of the readerresponse theorists who claim that since "texts frequently contain social dilemmas and conflicts", the reading process "demands personal responses from readers" (Yang, 2002, p. 50). The study presented so far clearly highlights two drastically different perspectives on literary analysis. There are research works trying to bridge the gap between the two (Rejan, 2017). However, a complete understanding of the two and their relative differences is yet to be achieved and this paper hopes to address that gap in literature.

\section{Methods of Research}

The present study employs the reader-response approach to re-read the tenets of the New Critics and the Reader-response theoreticians pointing out the similarities, differences, and commonalities of the two approaches. By moving in the wake of the reader-response theorists, the study negates the objectivity of the New Critics and supports Bleich's (1988) proclamation that "the study of literature and art cannot proceed independently of the study of the people involved in the artistic transaction" between the text and the reader (p. 203). Thus, the significance of this theory lies in proposing that the text is a function of its reader. The importance of this Reader-oriented theory is that almost all studies of literature fall under this rubric because all involve some sort of response.

\section{Reader-Response Criticism}

Like most approaches to literary analysis, the reader-response approach was conceived as a reaction to the earlier critical trend. The major proponents of this critical movement involve a long list of German, American and French critics: Jauss, Iser, Holland, Bleich, Fish, Culler and Barthes, to name just a few (Bressler, 1994). Though the reader-response critics are associated with different schools of criticism such as psychoanalytic criticism, structuralism, deconstruction, phenomenology and poststructuralism, they share certain features. They rejected the New Critics' objective approach; an objectivity that included both artist and critic. The New Critics cocoon the text in form to protect it from history, while the reader-response critics expanded it to culture and the reader's skilful perception. However, the implied suggestions within the New Critics' statements could not deny the effect on its readers. Richards's (1929) experience of practical criticism, for instance, demonstrates the efficiency of the reader in creating a variety of interpretations and thus opens the door to the coming generation of critics. The author acknowledges the subjective interpretations by the students who are originally shaped by their own cultural background. Consequently, the reader-response theorists advocate the invalidity of the objective approach where there is a multiplicity of meanings as there are readers: it is the reader 
who "coauthors the literary text" (Justman, 2010, p. 121). Moreover, reader-response theorists do not provide us with a single formula, for as Rabinowitz (1989) mentions, they:

are not working together from the same assumptions toward some common end; they have neither a shared methodology nor a clear pattern of growth. Rather, reader-critics combine an interest in reading with a wide variety of other critical and political concerns. (p. 82)

Thus, reader-response critics do not have one agreed-upon methodology for producing meaning, where it mainly results from the interaction between the text and the reader.

The significant role of the reader in the process of reading is emphasised. Critics claim the mutual transaction between the reader and text from which meaning emerges. It is rather a transactional experience stimulated by the text which elicits past thoughts, ideas and experiences from the reader. Rosenblatt (1978) emphasises that "the intrinsic value of a literary work of art resides in the reader's living through the transaction with the text" (p. 132). Amer (2003) likewise defines this transactional theory as follows:

It views the reading process as a transaction between the reader and the text in which the reader, with his past experiences, beliefs, expectations and assumptions, interacts with the perspectives in the text, and meaning is determined as the result of this transaction. Thus, reading, in this approach, is a reflective and creative process and meaning is self-contracted. (p.68).

The reader actively reads, receives, perceives, and thus contributes something to the text. Implicitly and generally, Rosenblatt (1978) refers to the New Critics when she declares that the poem is cooperatively produced by the reader. However, although Eliot (1933) agrees with the New Critics in their exclusion of the reader in their claim of the affective fallacy, Eliot himself does stress the importance of the reader in the production of meaning, which reflects his anticipation of the readerresponse's interest in the reader and the reading process. Eliot (1933) observes that:

The poem's existence is somewhere between the writer and the reader; it has a reality which is not simply the reality of what the writer is trying to 'express', or of his experience of writing it, or of the experience of the reader or of the writer as a reader. Consequently, the problem of what a poem 'means' is a good deal more difficult than it at first appears. (p. 30)

Similarly, Brooks and Warren (1976) mentioned that "the poem is an experience . . . deeply significant experience" and that the reader is "more aware of the depth and range of the experience" (p. 16). This implies the significance of the reader in the reading process, and hence his involvement.

\section{Reader-Response Practitioners: Various Orientations}

Although all reader-oriented critics focus on the reader and the reading process, they explore varieties of relationship between criticising subject and criticised object, and as a group they seem difficult to approach. The different focal point in each approach orients the theory differently. The following divisions are hopefully intended to clarify the different tilts and the major practitioners. 
Accordingly, their methodologies shall be classified into three major categories, which are not clear cut and with selected representatives:

1. Text-orientation represented by Culler (1980) and Barthes (2001).

2. Psychoanalytical and subjective orientation in the criticism of Holland (1968, 1975, 1980) and Bleich (1978, 1988).

3. Reception orientation. This is clear in the methods of Jauss (1988), Iser $(1978,1988)$ and Fish $(1980,1988)$.

\section{Text-orientation}

Much like the New Critics, this approach views the author as the origin of literary meaning. The focus here shifts to the system of rules in the language used and the competence of its receiver. The major proponents of this approach are the structuralists Culler and Barthes. This group of critics focuses on the reader's interaction with the text during the interpretive process. The text is important as it contains specific linguistic codes or signs which the reader has to interpret. Culler (1980) shifts the focus from the text to the "competence" of the reader (p. 105). According to Selden, Widdson \& Brooker (2005), Culler "sees the structure not in the system underlying the text but, in the system, underlying the reader's act of interpretation" (p. 75). Readers, Culler believes, can determine the rules governing interpretation and not those related to the writing of texts. In that case, the reader as defined by Culler (1980) is not a common one affected by his historical context but rather an interpersonal, "ideal reader" (p. 111). This sophisticated reader is "formed by purely literary norms or constraints" and has a perfect grasp of a "set of conventions" for reading literary texts (Lentricchia, 1980, p. 111). This links to Eliot's critic/artist who should have a "historical sense" and should be guided by "tradition". These two poles in Eliot's agenda appear to be the basis for Culler's "literary competence": both entail the wide knowledge of conventions and mastery of the language of the text.

Barthes (2001) also gives more importance to the reader in interpreting a text and proclaims that the old relationship between author and reader has changed. Therefore, several points for discussions could be offered: the text as an experienced activity, as open-ended, as symbolic and intertextual where the reader and text are linked during the process of reading. The author comes to his text only as a guest, which means that the author will reappear by the reader/critic. Like the New Criticism's rejection of the precept of the intentional fallacy in general or Eliot's impersonality in particular, Barthes (2001) argues against incorporating the intentional and biographical context of an author in interpreting a text: "To give a text an Author is to impose a limit on that text, to furnish it with a final signified, to close the writing" (p. 188). In Barthes's (2001) view, the meaning of a text is no longer dependent on its creator but lies exclusively in the language of the text as well as the impressions of the reader, or what the New Critics called the affective fallacy. By not viewing the author as the final authority of work, the unity of a text "lies not in its origin but in its destination" (Barthes, 2001, p. 189).

Barthes's tendency in locating meaning objectively in the text seems similar to the viewpoint of the New Critics, but what differentiates it is the creed that while the latter insist on arriving at one agreed-upon interpretation of a text, his theory denies this possibility. For Barthes, the text 
does not offer the reader a fixed meaning as the classical view but rather engages the reader to create strata of meanings. But the reader has to slough off themselves from any historical, biographical or psychological elements: "He is simply that someone who holds together in a single field all the traces by which the written text is constituted" (Barthes, 2001, p. 189). In this case, the reader meets with Eliot's critic who has to approach a work with a free mind, unaffected by their personal prejudices or preconceived notions.

However, the limitation of Barthes's popular clichés which went into entirely deleting the authority of the author is debatable. It cannot be denied that the emotions, feelings and thoughts of the author are the main motivation behind any text. Burke (1998) answers this argument through the deconstruction of anti-authorial texts. Many readers, Burke (1998) says, "have been convinced that - even taken on the level of its own premises - "The Death of the Author" is quite wrong and yet have been stymied by their inability to say quite why" (p. 22). The author to the text, is, according to Burke (1998), "the unitary cause, source and master to whom the chain of textual effects must be traced, and in whom they find their genesis, meaning, goal and justification" (Burke, 1998, p. 23). Thus, the text's language is created by its author, for the author organises it and shapes it that way.

\section{Psychoanalytical and Subjective Orientation}

The psychoanalytic critics Holland and Bleich show major concern with the influence of the reader's psychology, beliefs, thoughts and experiences in reacting to a text. The priority in their analysis lies in the affective experiences of these individualistic elements rather than in the language within the text. Holland (1980) adopts Freud's psychoanalytic approach in interpreting texts and finds that there is a transaction taking place between readers and the text. "Identity recreates itself . . that is all of us, as we read, use the literary work to symbolize and finally to replicate ourselves" (p. 124). At birth, Holland believes, readers receive primary identities from their mothers and over the course of life, these identities are developed and transformed into "identity theme(s)" through which they view the world (p.121). Holland $(1968,1975)$ argues that there is a transformation from the text, and through their personalities, readers construct unified interpretations. This shows the shift Holland made of the unity from the text to the reader. Evidently, readers have different interpretations of the same text because they unconsciously apply aspects of their life experiences to their reading on different texts. Holland (1980) claims that it is a building up of experience from a literary work that is characteristic for the reader. On this basis, the text then has no fixed meaning because readers' experiences are different.

Bleich's (1988) declares that "objectivity is almost a game played by the critics" to support their belief that "criticism presents its knowledge in the same form as the exact sciences", consequently, it will have equal "authority". On the contrary, the way these reader-response theorists treat interpretive knowledge shows that it is subjective and a "construct", and thus "they believe in critical pluralism". The producer of the text is one while the critical analysis is a ritual based on different readings (p. 200). Bleich (1988) finds the New Critics' objective approach "a fallacy" (p. 200).

Arab World English Journal for Translation \& Literary Studies 
Bleich (1978), like Holland earlier, links literary criticism with classroom pedagogy in which students and teachers interact in their multiple responses and then interpretations. Through his classroom practices, Bleich reached the conclusion that reading is subjective and meaning is located in the mind of the reader. In this sense, Bleich (1978) rejected the New Critics' idea that argues that meaning is objectively contained within a text. Moreover, Bleich differentiates between the readers' response to a text and their interpretation of it in which the former does not constitute a text's meaning. By working in groups, discussing and negotiating different responses to the literary text, readers can develop on the meaning of the text. The meaning, therefore, lies not in the text, nor in the response of one reader, but rather in the responses of a communal session who cooperate in producing one interpretation of the literary text. Bleich's classroom readings and interpretations are an extension of Richards's (1929) experience of practical criticism, which both came with too much subjective criticism. The limitation of this Hollandian and Bleichian criticism is that readers' identities get too involved in the text and consequently marginalise the text's aesthetic value.

\section{Reception Orientation}

The adherents in this group are Jauss and Iser, the two German luminaries of the Reception school (Rezptionsasthetik), as well as the American theorist Fish. Both Jauss (1988) and Iser (1978) share opinion about the freedom accorded to the reader's formation of meaning, finding the social conditions strait-jacket the reader and allow no variety of responses. By dismantling "the older construct of the text as the stable foundation of interpretation and literary history" the text "lives only through the reader and the history of the reader's involvement with it" (Holub, 1984, p. 149). Here, the text and the historical context of the reader play equal parts as the text serves as a trigger to the reader who then completes the process.

Affirming the importance of the reader's social context in the act of interpretation, Jauss (1988) asserts that texts are not adequately understood if on the focus is on how they were produced without taking into account how they were originally received. Jauss (1988) is against the New Criticism in its lack of historical dimension and against Marxist Criticism in considering texts as a merely historical product. In so doing, these approaches "deprive literature of a dimension that inalienably belongs to its aesthetic character as well as to its social function: the dimension of its reception and influence" (Jauss, 1988, p. 189-190), an approach that intersects with the New Historicist reading. Both approaches look at the reader as "a perceiving subject" and thus ignore his "genuine role" (p. 190). The link between a text and its reader has "aesthetic" as well as "historical" dimensions (p. 190). The aesthetic value lies in comparing a literary text with previous works. Historical dimension lies in the fact that the first reader's understanding of the text is enriched by the successive receptions of several readers. Therefore, Jauss (1988) called for the significance of the reader's reception of a text by using the term "horizons of expectations" (p. 191), which means that the reader's reception and understanding of the literary text differs from time to time because readers use different criteria to evaluate a literary text. Readers in different periods have different "horizons of expectations" that relate to their own social and cultural experiences. These "horizons of expectations" reject the possibility of forming one correct interpretation of the text. Jauss (1988) stresses that:

Arab World English Journal for Translation \& Literary Studies 
A literary work is not an object that stands by itself and that offers the same view to each reader in each period. ... It is much more like an orchestration that strikes ever new resonances among its readers and that frees the text from the material of the words and brings it to a contemporary existence. (p. 191)

For Jauss (1988), the meaning of a text is not static because readers over the course of time change the criteria of text's evaluation and what they value in a text differs from reader to reader. Texts, therefore, are actively altered according to the "horizons" within which they are received. In this sense, a final assessment of a literary work is impossible. This notion of the instability of reception/evaluation, or "horizon of expectations" can be traced back to Eliot (1972b) in the dynamic conception of "tradition" when stating that the artist must be aware of "the main current" and that "the mind of Europe ... is a mind which "changes" (p. 73).

The theory proposed by Iser (1978) is based on the notion that what matters is neither the text nor the reader but the effect of the text on its reader. This notion that links Iser to phenomenology emphasises on the perceiver. Any text, Iser (1978) insisted, has no meaning by itself and it comes to life only when read. The receiver recognises the given data and reorganises them to construct a meaning. Therefore, meaning is achieved only through the reader's consciousness who perceives and processes the text. This act of realisation that the reader accomplishes during reading gives meaning and aesthetic value to the text, completing the author's artistic value:

The literary work has two poles, which we might call the artistic and the aesthetic: the artistic pole is the author's text and the aesthetic is the realization accomplished by the reader. In view of this polarity, it is clear that the work itself cannot be identical with the text or with the concretization, but must be situated somewhere between the two. (Iser, 1978, p. 21)

According to Iser (1988), the text includes "gaps" or "blanks" that the readers have to fill through their active, creative participation, and thus determine the "indeterminacy" (p. 196). When readers concretise a text, they automatically look at it from their personal worldviews. Through their imagination, experiences, knowledge and "horizons of expectation", readers construct possible worlds from the open, incomplete texts, leading to different interpretations according to each individual reader.

Conversely, Fish (1988) defines meaning via union between reader and text. Readers select the meanings that fit their interpretive strategy. In his early phase, Fish (1980) was basically concerned with what the text in the process of reading does to the reader and not what it means, a notion that was developed later in his concept of "affective stylistic"(p. 70), contrasting the formalistic emphasis on the text as the only locus of meaning. Accordingly, his method focuses on what happens not in the text but in the minds of the individual readers in the course of reading, a conception associating him with phenomenology. However, Fish's (1980) reader is not an ordinary one but an "informed reader" (p. 86) trained in academic institutions, who has knowledge syntactically, semantically and knowledge of literary conventions. Texts include formal features which the reader can interpret. In that way, meaning is an experience that is socially conditioned and constituted during the reading process. 
Later towards the end of the seventies, shifting from the mode of phenomenology to poststructuralism, Fish (1988) moved from the "informed reader" to the "interpretive community" (p. 207) which means that each group of readers shares "interpretive strategies" and thus creates its own text (p. 204). These strategies, Fish (1988) claims, "exist prior to the act of reading and therefore determine the shape of what they read rather than, as usually assumed, the other way around" (p. 207). This idea is fully attacked by Scholes (1985) for two reasons. First, because by being a member of an interpretive community, the "interpreter lacks freedom, power and responsibility" and second, "it does not allow for any difference between understanding and belief" (p. 150). There must be differences between individual readers, and a consensus of meaning is an imposition.

The above survey demonstrates the heterogeneity and disunity of the reader-oriented theory that has become prominent since the seventies of the twentieth century. All agree that meaning is the creation of the reader. Like many schools of criticism, this reader-oriented criticism uses multiple approaches to textual analysis. The only serious drawback of the reader-response approach is the belief that meaning results from the reader's interpretation of the text while ignoring the author's relationship to the text. Accordingly, the study recommends that, through the reader's perspective, the author's presence is a major force where readers see different authorial intentions because they are creations of the reader and not the author. As the meaning is not a given or simply there in the text, the reader's freedom can make a variety of meanings of a text possible; texts are open-ended. However, it is now hard to find any literary theory that can dispense with the reader/perceiver.

\section{Discussion}

The study argues that, though the New Critics insisted on the objectivity of criticism, statements in their essays are controversial and would verify the subjectivity of criticism and the multiplicity of readings, and hence defeat their theoretical claim. Eliot (1971) for example, in his own claim that his projections in his masterpiece remain to him undefined implies that Eliot licenses readers to interpret the poem in the way they will. The emphasis on the complex relationship between past and present and his constellation of issues may be informative to different readings especially the "individual talent" embedded in tradition and adopted with great efforts. Brooks (1972) concludes with the image of "the phoenix" which the author says "burns, not like the taper at its own cost, but to live again. Its death is life" (p. 299). The author's supportive metaphor of the "phoenix" is the same connotative example of the variety of meanings in a text. Thus, every time a text is read, it gets a new life, a new reading or interpretation. Similarly, Richards in practical criticism was interested in the responses of participating students/readers. Their responses depended in their prejudices and personal beliefs more than literary elements. Richards (1972a) stresses the effect of the emotive language on the reader. Richards detects the multiplicity of connotative meanings in a text and introduces psychological reading as well as highlights the inner motives. In short, nothing in literature is a "given" or "determinate". Every text is dynamic, altered and open for the reader to fill in the "gaps" and deduce the "implied" meaning(s).

\section{Conclusion}

The earlier discussions highlight some commonalities and differences between the adherents of New Criticism and the reader-response approach., The study has concluded that the contradictory 
assumptions and underlying implication in the selected essays of the New Critics paved the way for reader-response theorists. The reader-response theory opened the door to marginalised dimensions in the text, proving that the addressee or reader is no longer seen as a passive recipient but the the meaning's producer or even co-writer. The present re-reading demonstrates that all texts address the reader and that the reader/critic reproduces the text and affects the public taste. Thus, a re-consideration of some doctrines of the New Critics proves them to be the root of some protocols of recent criticism. The New Critics motto of the close reading still exists as a controlling force in reader-response approach, but whereas the former focuses on the text per se, the latter is concerned with the mental activity of interpretation and how the text stimulates the reader's mind: the interaction. The study thus concludes that the ontological approach of the New Critics becomes incomplete and doubtful. It also demonstrates that the Reader-response approach offers the reader the freedom of interpretation as well as the application of any theory or method to the reading of the text. The study emphasizes that the transactional process between the reader and the text results in variation of individual readings and hence the indeterminacy and multiplicity of meanings. Hopefully, the study will contribute to scholarly research and opens new areas of investigation for further research who may ask the following: to what extent does adopting reader- response theory in teaching literary courses increase students' engagement in the learning process and enhance their critical thinking?

\section{About the author}

Dr. Alanoud Alghanem, is an assistant professor of English Literature in the Faculty of Languages at Princess Nourah Bint Abdulrahman University. She obtained a BA degree in 1994, MA in 2000, and PhD in 2009 and teaches courses in English Literature and translation. Her research interests include Irish poetry, Black British poetry and criticism.

ORCid: https://orcid.org/0000-0002-1368-5956

\section{References}

Abrams, M. H. (1993). A Glossary of Literary Terms (6 ${ }^{\text {th }}$ ed.). Orlando: Harcourt Brace Jovanovich.

Amer, A. A. (2003). Teaching EFL/ESL literature. Reading Matrix: An International Online Journal, 3(2), 63-73.

Arnold, M. (1970). The Function of Criticism at the Present Time. In Bate, W. J. (ed.), Criticism: The Major Texts (pp. 452-466). San Diego: Harcourt Brace Jovanovich.

Barthes, R. (2001). The Death of the Author. In Rice, P., \& Waugh, P. (eds.), Modern Literary Theory (pp. 185-189). New York: Oxford University Press.

Benveniste, E. (1971). Problem in General Linguistics. Oxford, Ohio: University of Miami Press. Bleich, D. (1978). Subjective Criticism. Baltimore: John Hopkins University Press.

Bleich, D. (1988). The Subjective Character of Critical Interpretation. In Newton, K. M. (ed.), Twentieth Century Literary Theory: A Reader (pp. 200-203). Basingstoke: Palgrave Macmillan.

Bressler, C. E. (1994). An Introduction to Theory and Practice Literary Criticism. New Jersey: Pearson Education

Brooks, C. (1947). The Well-Wrought Urn: Studies in the Structure of Poetry. New York: Harcourt, Brace. 
AWEJ for Translation \& Literary Studies Volume, 4 Number 4 October 2020

A Critical Controversy: Reader-Response Theoreticians

Alghanem

Brooks, C. (1972). The Language of Paradox. In Lodge, D. (ed.), $20^{\text {th }}$ Century Literary Criticism (pp. 292-304). London: Longman.

Brooks, C., \& Warren, P. (1976). Understanding Poetry $\left(4^{\text {th }}\right.$ ed $)$. New York, United States: Holt, Rinehart and Winston.

Burke, K. (1967). The philosophy of literary form: Studies in symbolic action ( $2^{\text {nd }}$ ed.). Louisiana: Louisiana State University Press.

Burke, S. (1998). The Death and Return of the Author: Criticism and Subjectivity in Barthes, Foucault and Derrida. Edinburgh: Edinburgh University Press.

Canary, R. H. (1982). T. S. Eliot: The Poet and His Critics. Chicago, United States: American Library Association.

Culler, J. (1980). Literary Competence. In Tompkins, J. P. (ed.), Reader Response Criticism from Structuralism to Post-structuralism (pp. 101-118). London: Johns Hopkins University Press.

Eliot, T. S. (1933). The Use of Poetry and the Use of Criticism. London, United Kingdom: Faber and Faber.

Eliot, T. S. (1972a). The Function of Criticism. In Lodge, D. (ed.), 20 ${ }^{\text {th }}$ Century Literary Criticism (pp. 77-84). London: Longman.

Eliot, T. S. (1972b). Tradition and the Individual Talent. In Lodge, D. (ed.), $20^{\text {th }}$ Century Literary Criticism (pp. 71-76). London: Longman.

Eliot, Valeri. (1971). The Waste Land: A Facsimile and Transcript of the Original Drafts, including the Annotations of Ezra Pound. Eliot, V. (ed.) New York: Harcourt Brace Jovanovich.

Fish, S. (1980). Literature in the Reader: Affective Stylistics. In Tompkins, J. P. (ed.), Reader Response Criticism: From Structuralism to Post-structuralism (pp.70-100). London: Johns Hopkins University Press.

Fish, S. (1988). Interpreting the Variorum. In Newton, K. M. (ed.), Twentieth Century Literary Theory: A Reader (pp. 203-209). New York: Palgrave Macmillan.

Holland, N. (1968). The Dynamic of Literary Response. New York: Oxford University Press.

Holland, N. (1975). Five Readers Reading. New Heaven and London: Yale University Press.

Holland, N. (1980). Unity Identity Text Self. In Tompkins, J. P. (ed.), Reader Response Criticism: From Structuralism to Post-structuralism (pp. 118-132). London: Johns Hopkins University Press.

Holub, R. (1984). Reception Theory: a Critical Introduction. London, New York: Methuen.

Iser. W (1988). Indeterminacy and the Reader's Response. In Newton, K. M. (ed.), Twentieth Century Literary Theory: A Reader (pp. 195-199). New York: Palgrave Macmillan.

Iser, W. (1978). The Act of Reading: A Theory of Aesthetic Response. London: John Hopkins University Press.

Jauss, H. R. (1988). Literary History as a Challenge to Literary Theory. In Newton, K. M. (ed.), Twentieth Century Literary Theory: A Reader (pp. 189-194). New York: Palgrave Macmillan. Justman, S. (2010). Bibliotherapy: Literature as exploration reconsidered. Academic Questions, 23(1), 125-135.

Lentricchia, F. (1980). After the New Criticism. Chicago, United States: University of Chicago Press.

Mills, S. (1997). Discourse. London: Routledge.

Arab World English Journal for Translation \& Literary Studies 
AWEJ for Translation \& Literary Studies Volume, 4 Number 4 October 2020

A Critical Controversy: Reader-Response Theoreticians

Alghanem

Rabinowitz, P. J. (1989). Whirl without End: Audience-Oriented Criticism. In Atkins, D. \& Morrow, L. (eds.), Contemporary Literary Theory (pp. 81-95). Amherst: University of Massachusetts Press.

Rejan, A. (2017). Reconciling Rosenblatt and the New Critics: The Quest for an" Experienced Understanding" of Literature. English Education, 50(1), 10-41.

Richards, I. A. (1929). Practical criticism: A study of critical judgment. London: K. Paul, Trench, \& Trubner.

Richards, I. A. (1972a). The Two Uses of Language. In Lodge, D. (ed.), $20^{\text {th }}$ Century Literary Criticism (pp. 111-114). London: Longman.

Richards, I. A. (1972b). Communication and the Artist. In Lodge, D. (ed.), 20 ${ }^{\text {th }}$ Century Literary Criticism (pp. 106-111). London: Longman.

Rosenblatt, L. M. (1978). The Reader, the Text, the Poem: The Transactional Theory of the Literary Work. London: Southern Illinois University Press.

Said, E. W. (1983). The world, the text, and the critic. Cambridge: Harvard University Press.

Scholes, R. (1985). Textual Power: Literary Theory and the Teaching of English. New Haven: Yale University Press.

Selden, R., Widdson, P., \& Brooker, P. (2005). A Reader's Guide to Contemporary Literary Criticism. Pearson Education LTD.

Tompkins, J. P. (Ed.). (1980). Reader Response Criticism: from Structuralism to Poststructuralism. London: Johns Hopkins University Press.

Yang, A. (2002). Science fiction in the EFL class. Language Culture and Curriculum, 15(1), 5060 .

Arab World English Journal for Translation \& Literary Studies 